多孔質アルミナセラミックスの機械的特性

\author{
大原 泰源江 1 ，中別府哲也汭，田中 伸一江1

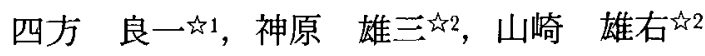 \\ 三木 康夫级 \\ 的大阪七メント新材料研究部，广597 貝塚市二色中町8-1.

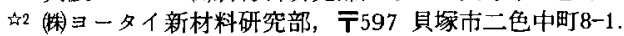

\title{
Mechanical Properties of Porous Alumina Ceramics
}

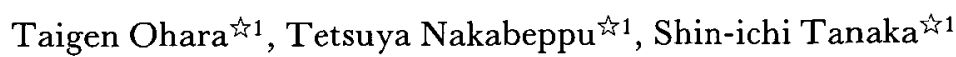

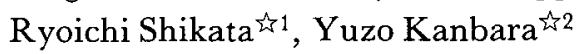 \\ Yusuke Yamasaki ${ }^{2}$ and Yasuo Miki ${ }^{2} 2$ \\ tr1 Advanced Material Research Laboratory, Osaka Cement Co., Ltd., 8-1 Nishiki Naka-machi, Kaizuka 597. \\ $\rightarrow 2$ Research \& Development Laboratories, Yotai Refractories Co., Ltd., 8-1 Nishiki Naka-machi, Kaizuka 597.
}

Received December 3, 1993

Porous alumina ceramics having a sandwich panel structure which consists of a porous layer sandwiched in the two thin high-density layers were prepared by the solid casting method using an alumina slip added air foam. Mechanical properties of the porous alumina ceramics with porosity of 10 to $80 \%$ were measured. The average bending strengths showed the higher values, e.g., $100 \mathrm{MPa}$ at $40 \%$ porosity and $20 \mathrm{MPa}$ at $75 \%$ porosity, as compared with customary porous alumina ceramics. The bending strength decrease of the porous alumina ceramics with porosity was not so high as an empirical equation by Coble and Kingery. It was considered that the enhancement of bending strength resulted in the existence of high-density layers at surface of porous alumina ceramics.

\section{1 舶言}

アルミナセラミックスは，機械的特性と耐熱性に 優れ、エンジニアリングセラミックスとして広く利 用されてきた。近年, アルミナセラミックスを種々 の方法により意図的に多孔化し，軽量化，断熱性の 付与, 低熱容量化，および内部空隍の利用などを行 い，断熱材，妒材，焼成用道具材，触媒担体、フィ ルター，吸着材等，新たな用途展開が模索されてい
る、しかしながら，30\%を越えるような高い気孔率 を有する多孔質アルミナセラミックスでは，強度の 低下が著しく，強度をあまり必要としない用途に限 られている.この多孔質アルミナセラミックスの機 械的性質については，CobleとKingery" が曲げ強度 について，Ryshkewitch ${ }^{2)}$ が圧縮強度について報告し ているが，気孔率 $50 \%$ を超える多孔質アルミナセラ ミックスについての報告はほとんど見られない。こ 
れは，50\%以上の高い気孔率を有する多孔質アルミ ナセラミックスの成形が難しかったこと，またその ような多孔体では，強度が極端に小さく，評価が難 しかったことによると考えられる、そこで本研究で は，アルミナセラミックスの軽量化と高強度化を同 時に满足させることを目的とし，成形体表面に成形 体の厚さに対して十分薄い緻密質層を有し，内部が 多孔質層から成る、サンドイッチパネル棈造を持つ 多孔質アルミナセラミックスを作製し，その成形体 の特性, 特に気孔率と強度の関係を検討した。

\section{2 実䠑方法}

\section{1 試料の作製}

実験に用いたアルミナ原料は，昭和電工製の易焼 結性アルミナ(AL-160SG-4; 化学組成 $\mathrm{Al}_{2} \mathrm{O}_{3} 99.9$ wt \%, $\mathrm{Hg} 00.05 \mathrm{wt} \%$; 平均粒子径 $0.7 \mu \mathrm{m})$ を使用し た.このアルミナ粉末と水を3:1の割合で混合して5 $\mathrm{kg}$ とした後, 解膯剤とバインダーを添加し、ボール ミルで20時間混合し，アルミナスラリーを作製した。 このスラリーに，蛋白系起泡剂を用い，所定のスラ リー比重となるように気泡を混合し，気泡導入スラ リーを調製する。これを石音型内に流し込み，十分

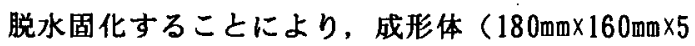
$\mathrm{mm}$ )を得た。成形体は室温で十分乾燥した後，1500 ${ }^{\circ} \mathrm{C} て ゙ 2$ 時間焼成した。

\section{2 キャラクタリゼーション}

得られた焼結体の断面構造および做棬造観察は， 光学影微鏡および走查型電子顕微鏡 ( S E M : J S M-5400）を用いた，作製した多孔質アルミナセラミ ックスの機珹的性質は三点曲げ強度試験により評価 した．この時，用いた強度試験片は，焼結体（4mm厚） をダイヤモンドカッターで40 mm $\times 4 \mathrm{~mm} \times 4 \mathrm{~mm}$ に加工し，

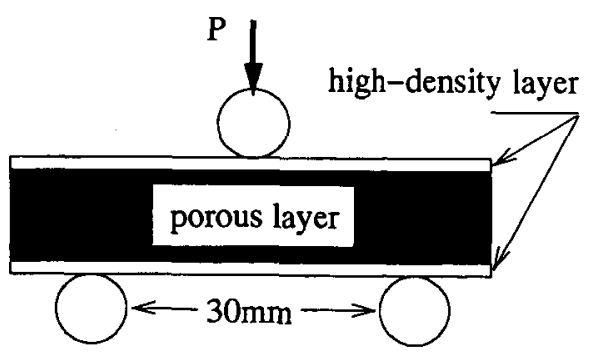

Fig.1 Schematic illustration of bending test in this study.
Fig.1のように表面緻密質層を有する面を各々圧縮, 引っ張り面に配置し，島津製作所製万能試験機（A G-20k D N ) を使用し，スパン長さ30mm，クロスへ ッド速度 $0.5 \mathrm{~mm} / \mathrm{min}$ て荷重を加え，破增強度を求めた．

\section{3 結果および考腺}

\section{1 成形}

従来，サンドイッチパネル構造を有するセラミッ クスは，多孔質セラミックス焼結体の表面に，所望 の厚さよなるようにスラリー状のセラミックス粉末 を染布し，再焼成することにより作製されてきた。

しかしながらここの方法ではセラミックス粉末と多 孔質セラッミクス焼結体の焼成収縮が不均一である ため, 十分な焼結性が得られ難く，その結果，表面 緻密質首の強度という点で問題があった。 そこで本 研究では，素地の段階で表面緻密質層と多孔質層を 同時に一体成形することを目的とし，アルミナスラ リー中に気泡を湿合した気泡導入スラリ一を用いた 固形鋳込み法により，サンドイッチパネル構造を有 する多孔質アルミナセラミックスの作製を試みた。 その結果，多孔斦層の両面に緻密質層を有する，気 孔率10-80\%の成形体が得られた。

\section{2 多孔質セラミックスの構造と見かけの気孔率}

焼結後，得られた成形体の見かけ気孔率をTable. にに示す，気孔率が25，46，および67\%の試験片の断 面光学䫓微鏡写真をPhoto. 1(a)，(b)，および(c)に 各々示す. 各試験片ともに，内部に多数の球形気孔 が導入されており，また表面には気孔を含まない緻 密質層が形成されていた。気孔の大きさは，気孔率 の增加とともに大きくなっている。これは，アルミ ナ粉末スラリー中の気泡の安定性によるものと考え られる．また，いすれの成形体においても，気孔径

Table 1 Bulk density and porosity of the sintered bodies.

\begin{tabular}{cr} 
bulk density $\left(\mathrm{g} / \mathrm{cm}^{3}\right)$ & porosity $(\%)$ \\
\hline $3.65 \pm 0.05$ & $8 \pm 1$ \\
$2.99 \pm 0.04$ & $25 \pm 1$ \\
$2.15 \pm 0.02$ & $46 \pm 1$ \\
$1.52 \pm 0.20$ & $62 \pm 5$ \\
$0.83 \pm 0.10$ & $79 \pm 3$
\end{tabular}



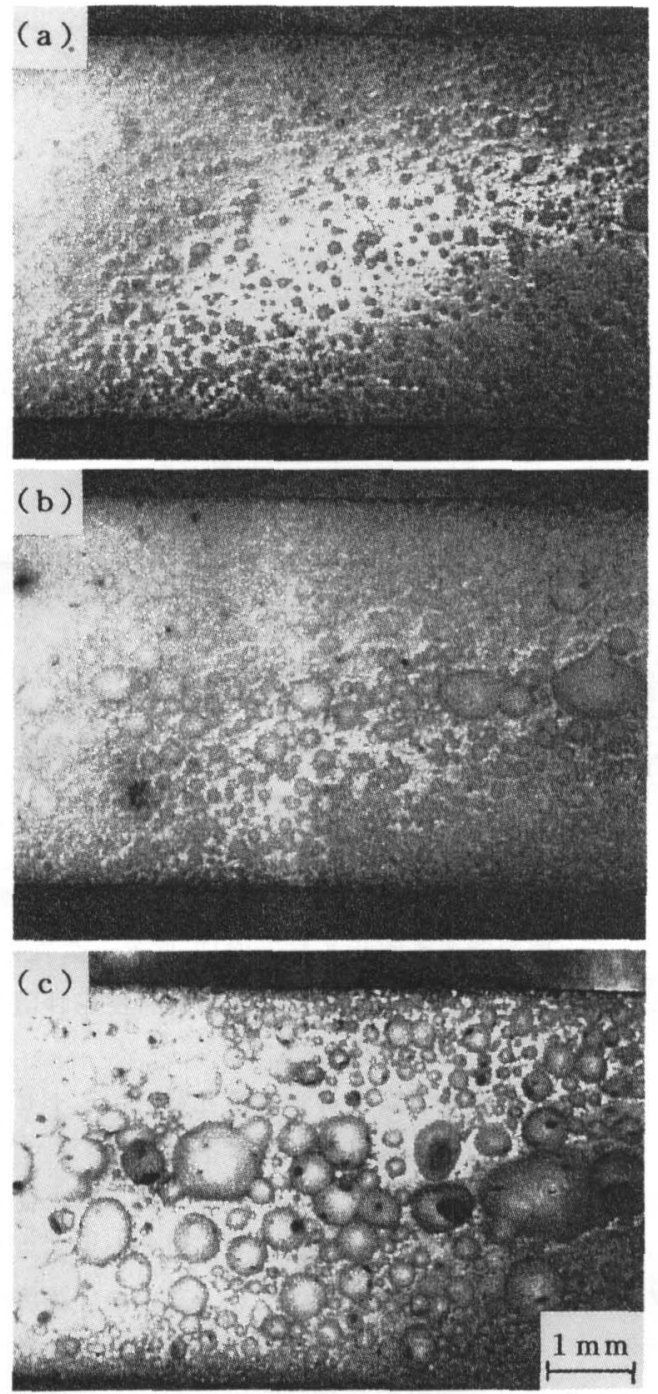

Photo.1 Optical micrographs of the sectional view of the samples having (a) $25 \%$, (b) $46 \%$ and (c) $67 \%$ porosity, respectively.

は表面近くから中心部に近い程大きくなる傾向を示 しており,これはスラリーの着肉過程における気泡 の成長が原因と考えられる.

Photo. 2(a)，(b)に気孔率 25，80\%の試験片の断 面 S E M写真を示す. 各試験片の粒子径は，およそ 1-3 $\mu$ mであり, 気孔率の違いによる粒子間結合と粒 成長の度合いの変化は認められなかった。

\section{3 三点曲げ強度}

作製した試験片の三点曲げ強度と気孔率の関係を, Fig. 2に示す. 測定は各気孔率につき，15本ずつ行っ た. 曲け強度は気孔率が增加するに伴い, 徐々に減 少し，気孔率 $40 \%$ で約 $100 \mathrm{MPa}, 75 \%$ の高気孔率にお
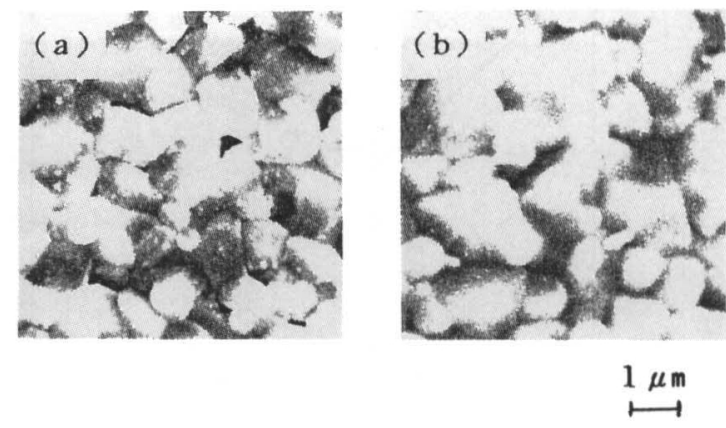

Photo.2 Scanning electron micrographs of the sections of the samples having (a)25\% and (b) $80 \%$ porosity.

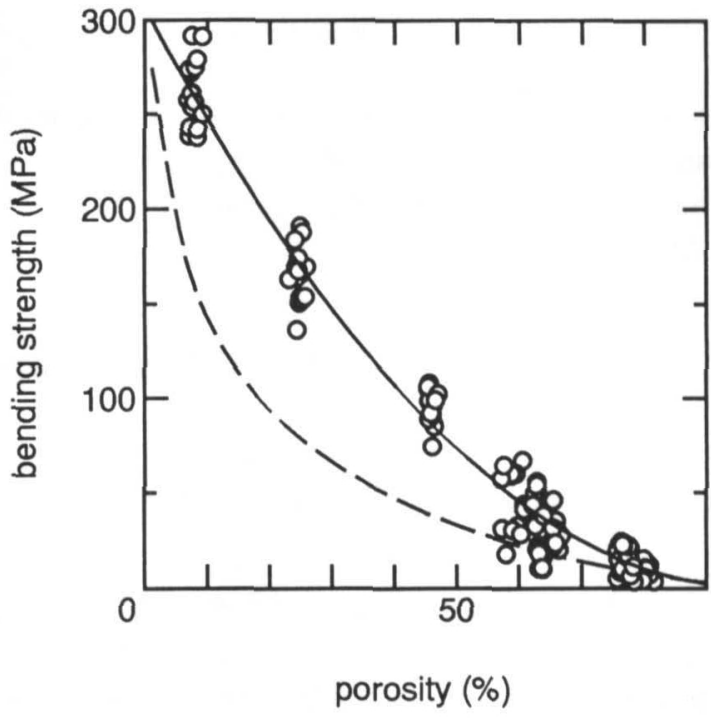

Fig. 2 Change in bending strendth with porosity of the samples (solid lines), and an empirical functions determined by Coble and Kingery ${ }^{1)}$ (broken lines).

いても約20MPaという高い値を示した。 一方, 図中の 破線は, CobleとKingery ${ }^{11}$ が求めた多孔質アルミナ セラミックスの四点曲げ強度 $\sigma$ (p.s. i. ) と気孔率 $\mathrm{p}$ の関係を示す経験式から，単位換算をして求めた 值である.

$$
0.6 \mathrm{p}=\exp \{-\sigma / 8000(1-\mathrm{p})\}
$$

この経験式によれば気孔率が $0-20 \%$ で急激に強度が 低下するのに対し, 今回得られた試験片の曲げ強度 の気孔率依存性は，非常に綅やかであった，試験方 法が異なるため, 曲げ強度の値を単純に比輘するこ とはできないが, 試験条件による差異を考虑しても, 今回作製したサンドイッチ構造を有する多孔質アル 


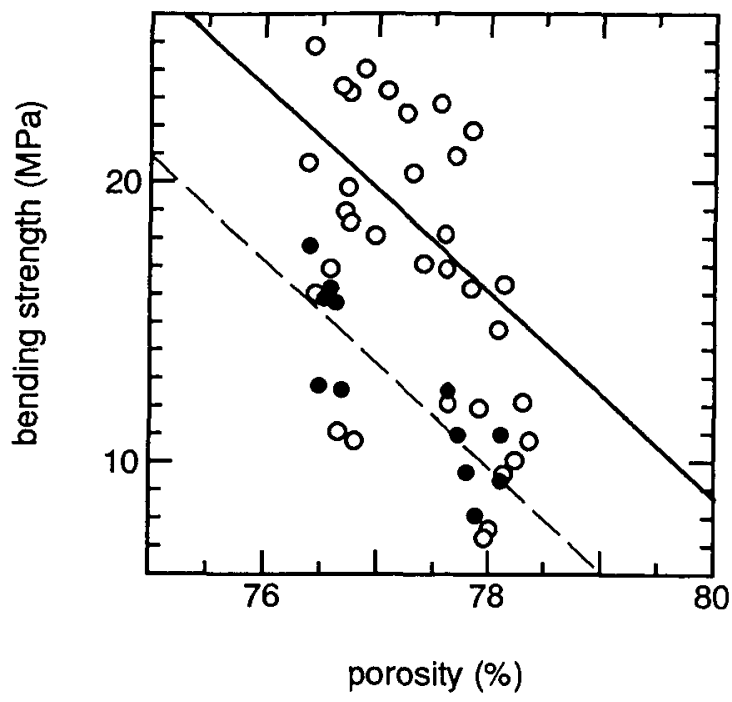

Fig.3 Effect of high-density layers on bending strength. Open and solid circles show the strengths of the samples, having high-density layers, and grinded away high-density layers, respectively.

ミナセラミックスは高い強度を示していると言える。 これは,アルミナの粒子径が小さいこと, 成形体中 に存在する気孔の形状が球形であること，および成 形体表面に剛性の高い緻密質層を有することに起因 すると考えられる。

表面緻密質層の曲げ強度への影整を調べるため, 表面敉密質層を有する試験片と，表面研削により表 面緻密質層を削除した気孔率75-80\%（研削後）の試 験片の曲げ強度を测定し，Fig.3に示した。図から明 らかなように気孔率75-80\%において，表面緻密質首 を有する試験片の方が，およそ5MPa高い值を示し， 表面緻密質層が曲け強度の增大に奇与していること が認められた. Fig.4に気孔率75-80\%の試験片の強 度と表面緻密質層の厚さとの関係を示す，緻密質首 の厚さが大きくなるに伴い，曲げ強度は增加する傾 向にあり、これらの成形体がサンドイッチ㭗造体と しての特性を有している゙'ことが分かる.

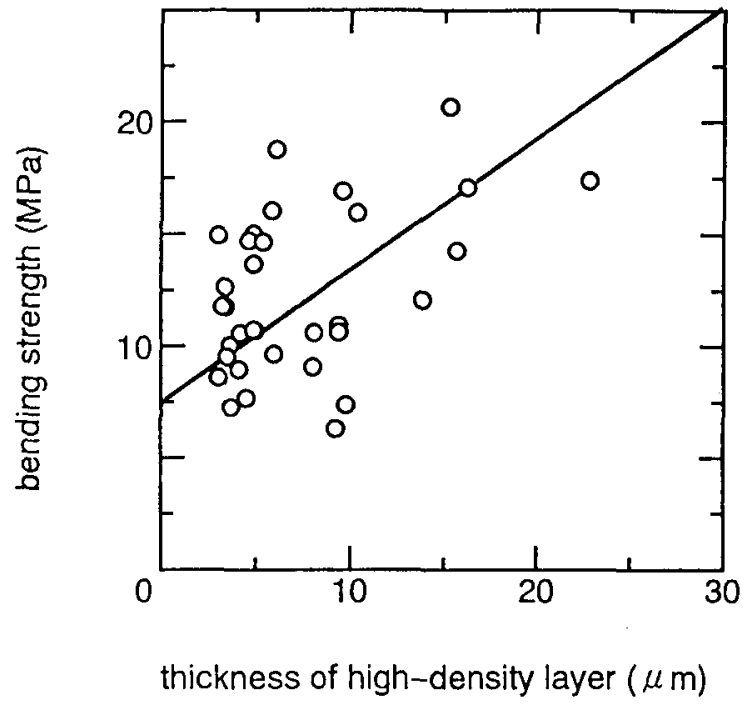

Fig. 4 Bending strength vs thickness of high-density layer of the samples with $75-80 \%$ porosity.

$$
4 \text { まとめ }
$$

表面に緻密質層を有する気孔率 10-80\%の多孔質ア ルミナセラミックスを作製し，機械的特性を評価し た結果，以下の知見を得た。

（1）表面に緻密質層を有する多孔質アルミナセラ ミックスが，銤込み成形法により得られる。

（2）気孔率の增加に伴う曲け強度の低下は，従来 の多孔質セラミックスと比較して，緩やかであった。

（3）表面絰密質層の奇与により，高い曲げ強度を 示す.

（4）同じ気孔率の焼結体の曲げ強度は，表面緻密 層の厚さが增す程，大きくなる.

\section{文就}

1) R. L. Coble, I. D. Kingery: J. Am. Ceram. Soc. , 39 (1956) 377.

2) E. Ryshkewitch: J. Am. Ceram. Soc. , 36 (1953) 65.

3) L. J.Gibson, M. F. Ashby:CELLULAR SOLIDS-Structure \& Properties, Chapter 9. 